$\begin{array}{lll}\text { Department } & : & \text { Biochemistry } \\ \text { Field of study } & : & \text { Biochemistry } \\ \text { Scientific Degree } & : & \text { M. Sc } \\ \text { Date of Conferment: } & \text { Mar. 17, 2021 } \\ \text { Title of Thesis : } & \text { BIOCHEMIC }\end{array}$

\title{
AL STUDIES ON SOME AROMATIC OR MEDICINAL PLANTS
}

\section{Name of Applicant: Shahen Rashwan Ahmed Mosa}

Supervision Committee:

- Dr. Sh. N. Draz : Prof. of Biochemistry, Fac. of Agric., Menoufia Univ.

- Dr. Samia M. Khalil: Prof. of Biochemistry, Fac. of Agric., Menoufia Univ.

- Dr. S. A. El Kodsy : Prof. of Biochemistry, Fac. of Agric., Menoufia Univ.

\begin{abstract}
Cichorium intybus and Portulaca oleracea plants native to the north Africa, especially in Egypt have been chosen for such study due to their importance both as food and as medical plants for treating several common diseases.

The present study analyzes chemical and phytochemical constituentes of Portulaca oleracea and Cichorium intybus and evaluates their therapeutic roles on liver, kidney functions and complete blood count in $\mathrm{H} 2 \mathrm{O} 2$ intoxicated rats.

Six groups of experimental animals are fed on basal diet, five of them intoxicated with $\mathrm{H} 2 \mathrm{O} 2$ in drinking water then treated with Portulaca oleracea and Cichorium intybus extracts.

This study shows that the total phenolics and total flavonoids contents in Cichorium intybus extracts are higher than that in the Portulaca oleracea extracts.

Cichorium intybus extract at orally dose of $75 \mathrm{mg} / \mathrm{kg}$ bw improve liver, kidney functions and normalize hematological parameters. It also decreases the MDA level, increases SOD and CAT activities.

Cichorium intybus has hepatorenal protective effect as it can protect tissue from free radicals and may provide a cushion for a prolonged therapeutic option against liver and kidney diseases without harmful side effects.
\end{abstract}

Key words: Cichorium intybus - Portulaca oleracea - Phenolics - Flavonoids antioxidant 


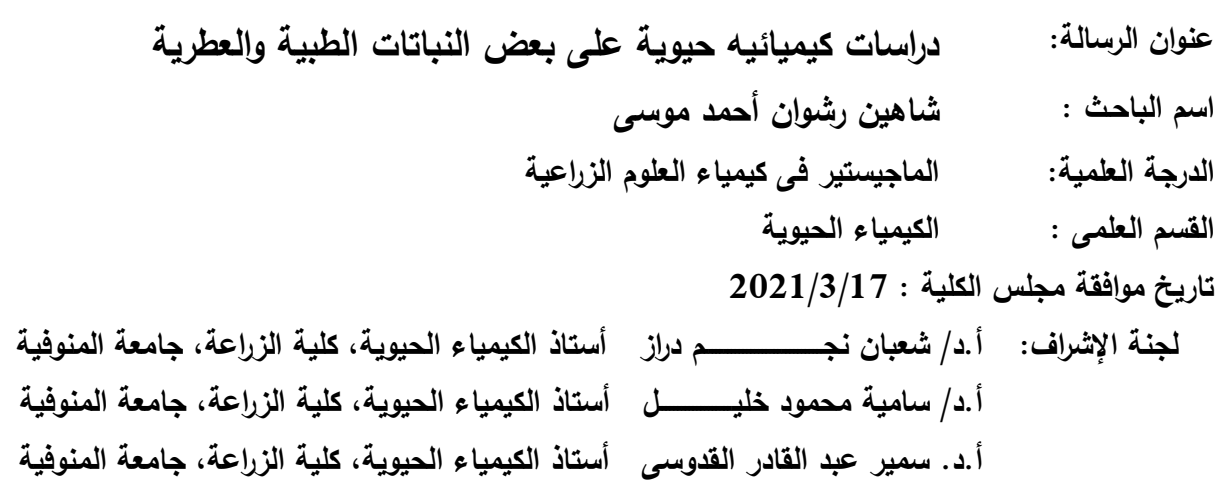

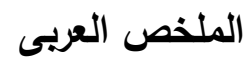

تم اختيار نباتات الثكوريا والرجلة ، لمثل هذه الدراسة نظرًا ألهميتها كفذاء ونباتات طبية لعالج العديد من ألمراض

هاف الاراسة الحالية هو تقدير المكونات الكيميائية لمستخلصات نباتي الثكوريا والرجلة و تقييم التاثيرات العالجية

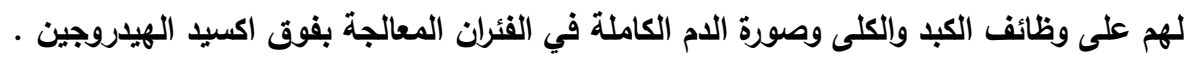
تم تقسيم الفئران الي ستة مجموعات ، تم اعطاء فوق اكسيد الهيدروجين الي خمس مجموعات تسمم مياه الثرب ثلثم عولجت بمستخلصات نباتات الثكوريا والرجلة . أظهرت هذه الاراسة أن إجمالي محتوى الفينوالت وإجمالي مركبات الفالفونويد في مستخلصات الثكوريا أعلى من تلك الموجودة في مستخلصات الرجلة.

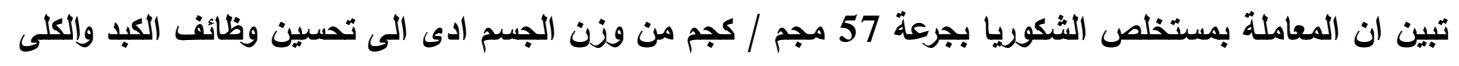

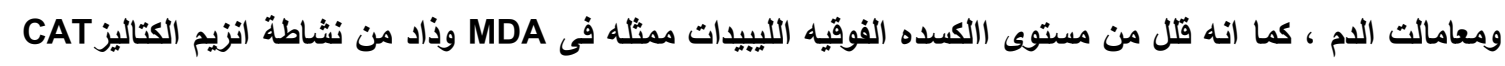
والسوير اكسيد ديس ميوتازSOD وهو احد مضادات الكسده النزيميه .

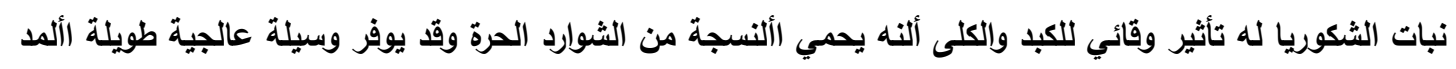
ضد أمراض الكبد والكلى دون آثار جانبية ضارة. 